DOI: 10.19085/journal.sijbpg030101

\title{
Financial Crisis and Europe: An eventual post-scenario analysis
}

\author{
Mike Susan \\ Humboldt-Universität zu Berlin, 10099 Berlin, Germany.
}

OScholedge International Journal of Business Policy \& Governance (ISSN 2394-3351), Vol.03, Issue 01 (2016) pg1-4. Published by: Scholedge R\&D Center [www.theSCHOLEDGE.org] [Email: sijbpg@scholedge.org]

\begin{abstract}
It is a typical abstain of political strategists that you ought not release a decent emergency to squander. Seven years on from the beginnings of the worldwide money related emergency, we can make an evaluation of whether that saying was taken after. The reaction in Europe was generally one of expanded government obtaining, counterbalance by bundles of expense rises and spending cuts. The methodologies in France, Germany, Ireland, Italy, Spain and the United Kingdom have been in a few ways comparative, however essential contrasts in a critical position of assessments and cuts, in the zones focused on and in the sorts of family units influenced have permitted us to make some unmistakable inferences about the effect of the Great Recession.
\end{abstract}

Keywords: Financial crisis, economic slow down, financial crunch, European markets

\section{Introduction}

In the years prior to 2007/2008, Ireland and Spain seemed to have the most beneficial monetary positions; they had run general spending plan surpluses for in any event the previous three years. Nonetheless, with the onset of the emergency, it rapidly turned out to be clear this position was propped up by unsustainable incomes, from the property market specifically. As the outline beneath demonstrates, the money related emergency prompted a significant weakening in the obvious fundamental quality of Ireland's and Spain's open accounts.

Albeit enduring somewhat less extremely, France, Italy and the UK additionally saw their fundamental open accounts debilitate, each by a little more than $5 \%$ of GDP. At the end of the day, had they made no strategy move by any means, they would have wound up obtaining more than $5 \%$ of GDP all the more consistently, for eternity.

The main special case was Germany, whose open accounts were - in the long haul unaffected by the Great Recession. Germany was the one and only of the six nations for whom this resembled a "course reading" subsidence; a brief increment in getting took after by a brisk come back to ordinary times. 


\section{Financial reaction}

There have been some altogether different arrangements went for managing the monetary issues confronted. France and Italy have both depended moderately vigorously on raising duties, instead of cutting spending, to diminish getting (as the outline appears). Before the end of 2014, 66\% of the measures actualized in France were gone for boosting income and $33 \%$ at decreasing spending. Both France and Italy are on course to wind up higher assessment, higher spending and higher obtaining nations than they were before the emergency hit.

Interestingly, the UK has depended essentially on slices to open spending: up to the end of $2014-15,82 \%$ of financial measures in the UK were spending cuts, as the figure appears. The outcome is that the UK is on course to have a lower level of spending, a comparable level of tax assessment, and a lower level of getting than pre-emergency.

\section{Comparable on expense, distinctive on spending}

Every nation has raised assessment to some degree, and the way of the expense increments actualized appears some intriguing likenesses. France, Ireland, Italy, Spain and the UK all expanded VAT rates and social protection commitments. France, Spain and the UK additionally actualized pay charge rises went for the most astounding salary people, while France and the UK both diminished organization charge rates while enlarging the base for this assessment.

The nations have, nonetheless, settled on rather distinctive decisions about spending. France, Italy and Spain abstained from cutting welfare glaring difference, a distinct difference to Ireland and the UK where slices to advantage installments for working age grown-ups assumed a noteworthy part. France and the UK have both managed relative insurance to spending on wellbeing and instruction, while Italy and Spain have cut these administrations more profoundly than other administration zones.

Nations have additionally settled on different options about which families ought to hold up under the brunt. In Italy family units with kids have lost less from duty and advantage changes than retired person families; the converse is valid in Ireland and the UK.

\section{Benefitting as much as possible from it?}

With France, Ireland, Italy, Spain and the UK executing extensive financial modification since the onset of the Great Recession, we may trust that policymakers would have utilized this minute to enhance the effectiveness of the duty framework and open spending in their nations. On the other hand, in any event, we would trust that they didn't fuel existing inefficiencies. Sadly, by and large, the financial reaction to the emergency has been a missed open door.

In France, while the new corporate duty credit (which is registered on individual profit of firms' workers) is welcome, it would have been exceptional to just decrease the moderately abnormal state of business government disability commitments. 
In Ireland, changes have pointlessly made vulnerability and twists. There has been a progression of VAT changes, while capital additions charge has since October 2008 been expanded from $20 \%$ to $22 \%$, then to $25 \%$, then to $30 \%$ and after that to $33 \%$.

The UK charges VAT on a moderately contract scope of merchandise - exempting things like certain sustenances and youngsters' dress. This makes twists in the economy: firms are incentivised to create products that are not subject to VAT and customers are urged to buy a greater amount of these sans vat merchandise than they generally would. In this way, the expansion in the principle rate of VAT will have come at the expense of expanding these mutilations.

The UK pay charge plan has likewise been made extensively more convoluted; take the presentation of a transferable expense remittance for wedded couples, and the decreasing without end of kid advantage from high wage folks.

\section{Remarks}

With numerous nations as yet running shortages in abundance of $2 \%$ of national salary and having a load of government obligation well above pre-emergency levels, this won't be the end of the story. Where there is a requirement for further spending cuts and/or charge rises, these could be an open door for nations to make changes that enhance the proficiency of duty and advantage frameworks. In any case, the lesson from the changes made so far is that we maybe should not to be excessively idealistic. We might need to settle for changes that don't add to existing inadequacy.

\section{References}

Acemoglu, D., Johnson, S., \& Robinson, J. (2005). The rise of Europe: Atlantic trade, institutional change, and economic growth. American economic review, 546-579.

Bernanke, B. S. (1983). Non-monetary effects of the financial crisis in the propagation of the Great Depression.

Blyth, M. (2001). The transformation of the Swedish model: economic ideas, distributional conflict, and institutional change. World Politics, 54(01), 1-26.

Chakrabarti, R., \& Roll, R. (2002). East Asia and Europe during the 1997 Asian collapse: a clinical study of a financial crisis. Journal of Financial Markets, 5(1), 1-30.

Crawford, B., \& Lijphart, A. (1995). Explaining political and economic change in postcommunist eastern Europe old legacies, new institutions, hegemonic norms, and international pressures. Comparative Political Studies, 28(2), 171-199.

Gasiorowski, M. J. (1995). Economic crisis and political regime change: An event history analysis. American political science review, 89(04), 882-897.

Karanikolos, M., Mladovsky, P., Cylus, J., Thomson, S., Basu, S., Stuckler, D., ... \& McKee, M. (2013). Financial crisis, austerity, and health in Europe.The Lancet, 381(9874), 1323-1331. 
Karolyi, G. A. (2002). Did the Asian financial crisis scare foreign investors out of Japan?. Pacific-Basin Finance Journal, 10(4), 411-442.

Kurzer, P. (1993). Business and banking: Political change and economic integration in Western Europe. Cornell University Press.

Landes, D. S. (2003). The unbound Prometheus: technological change and industrial development in Western Europe from 1750 to the present. Cambridge University Press.

Lesthaeghe, R. (1983). A century of demographic and cultural change in Western Europe: An exploration of underlying dimensions. Population and development Review, 411-435.

Stuckler, D., Basu, S., Suhrcke, M., Coutts, A., \& McKee, M. (2009). The public health effect of economic crises and alternative policy responses in Europe: an empirical analysis. The Lancet, 374(9686), 315-323.

Thurow, L. C. (1992). Head to head: The coming economic battle among Japan, Europe, and America. Granite Hill Publishers.

Vis, B., Van Kersbergen, K., \& Hylands, T. (2011). To what extent did the financial crisis intensify the pressure to reform the welfare state?. 